\title{
Integrated Test Schedule for Buried Waste Integrated Demonstration
}

\author{
J. T. Brown \\ J. K. McDonald
}

Published May 1992

\section{Idaho National "'ngineering Laboratory \\ EG\&u Idaho, Inc. Idaho Falls, Idaho 83415}

Prepared for the

U.S. Department of Energy
Offlce of Environmental Restoration and Waste Management Under DOE Idinho Field Orilce
Contract DE-ACO7-76iD01570




\section{Integrated Test Schedule for Buried Waste Integrated Demonstration}

EGG-WTD-10105

Prepared by:

$\frac{J K}{1}$ McDonald

J. K. McDonald

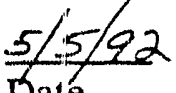

Bate

Reviewed by:

Buried Waste Integrated Demonstration Program Manager

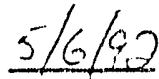

Date

Approved by:

Buried Waste Integrated Demonstration Coordinator
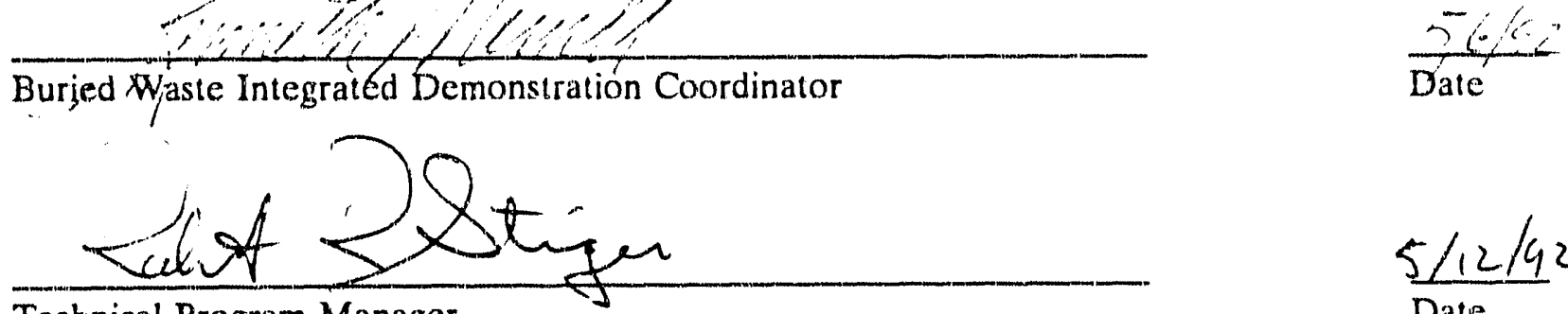

$5 / 12 / 42$

Technical Program Manager

Date 


\begin{abstract}
The Integrated Test Schedule incorporates the various schedules the Buried Waste Integrated Demonstration (BWID) supports into one document. This document contains the Federal Facilities Agreement and Consent Order schedules for the Idaho National Engineering Laboratory, Hanford Reservation, Oak Ridge Reservation, and Fernald Environmental Materials Center. Included in the Integrated Test Schedule is the Buried Waste Integrated Demonstration "windows of opportunity" schedule. The "windows of opportunity" schedule shows periods of time in which Buried Waste Integrated Demonstration Program-sponsored technology demonstrations could support key decisions in the Federal Facilities Agreement and Consent Order. Schedules for the Buried Waste Integrated Demonstration-sponsored technology task plans are categorized by technology area and divided by current fiscal year and out-year. 'Total estimated costs for Buried Waste Integrated Demonstrationsponsored Technology Task Plans for FY -92 through FY-97 are $\$ 74.756 \mathrm{M}$.
\end{abstract}





\section{SUMMARY}

The Department of Energy (DOE) Office of Technology Development (OTD) has initiated the Buried Waste Integrated Demonstration Program to identify, develop, and demonstrate advanced remediation technologies that support DOE's environmental restoration objectives. The Integrated Test Schedule's purpose is to integrate individual Buried Waste Integrated Demonstration (BWID) Program-sponsored technology schedules and to show the linkage between BWID, the Environmental Restoration Program, and the Federal Facilities Agreement and Consent Order.

The Environmental Restoration :rogram, BWID's primary customer, is responsible for implementing the Federal Facilities Agreement and Consent Order (FFA/CO). Federal Facilities Agreement and Consent Order schedules included in this document are for the Idaho National Engineering Laboratory (INEL), Hanford Reservation, Oak Ridge Reservation, and Fernald Environmentai Materials Center. To support the Environm ntal Restoration Program and the FFA/CO, BWID has identified "windows of opportunity." "Windows of opportunity" are periods of time in which technology demonstrations could support key decisions in the FFA/CO scope. Included in the Integrated Test Schedule is the "windows of opportunity" schedule for the INEL FFA/CO.

The Technology Test Plans (TTPs) sponsored by BWID are grouped by the Integrated Test Schedule in the following categories:

- Analysis, evaluation, and technical program support

- Characterization

- Retrieval

- Pretreatment/treatment

- Storage

- Transportation

- Disposal.

Schedules for the TTPs are categorized and divided by current fiscal year and out-year. These schedules summarize informaion from BWID TTPs approved as of February 1992. They are a compilation of selected activities and milestones. Categories featured for FY-92 are characterization, retrieval, pretreatment/treatment, technical program support, analysis, and evaluation.

Total estimated costs for BWID-sponsored TTPs for FY-92 through FY-97 are $\$ 74.756 \mathrm{M}$. For FY -92 , the estimated cost is $\$ 19.4 \mathrm{M}$. Cost distribution is shown in the Integrated Test Schedule by TTP, fiscal year, and category. 


\section{CONTENTS}

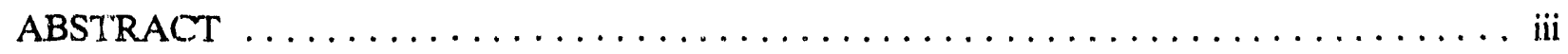

SUMMARY $\ldots \ldots \ldots \ldots \ldots \ldots \ldots \ldots \ldots \ldots \ldots \ldots \ldots \ldots \ldots \ldots \ldots \ldots \ldots \ldots \ldots$

ACRONYMS $\ldots \ldots \ldots \ldots \ldots \ldots \ldots \ldots \ldots \ldots \ldots \ldots \ldots \ldots \ldots \ldots \ldots \ldots \ldots \ldots \ldots \ldots \ldots$

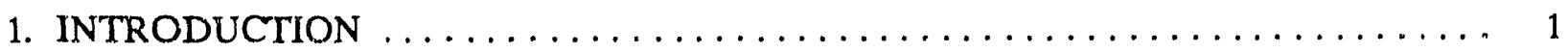

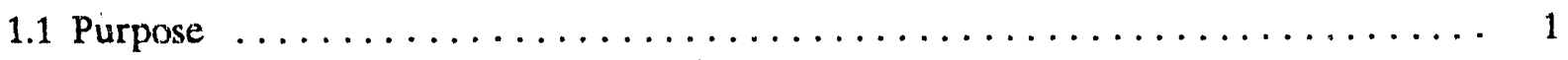

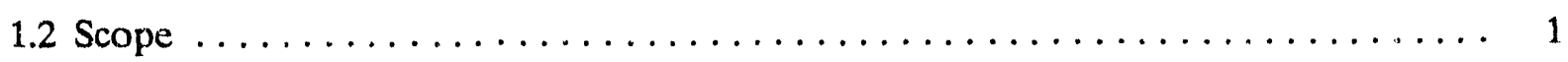

?. ENVIRONMENTAL RESTORATION PROGRAM NEEDS $\ldots \ldots \ldots \ldots \ldots \ldots \ldots \ldots$

2.1 Federal Facility Agreement and Consent Order $\ldots \ldots \ldots \ldots \ldots \ldots \ldots \ldots$

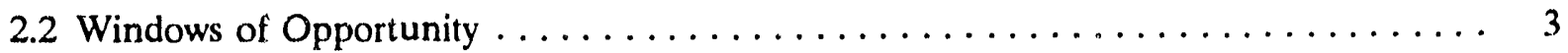

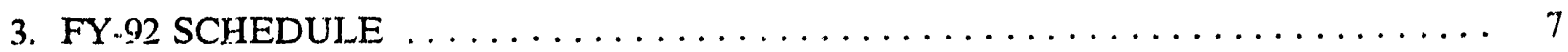

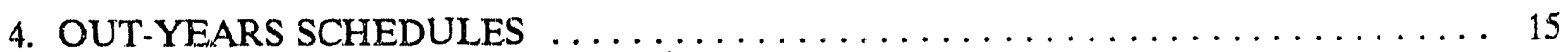

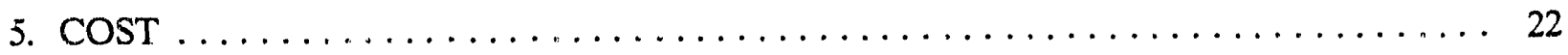

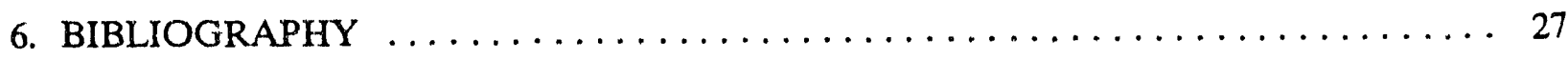

\section{FIGURES}

1. Federal Facility Agreement and Consent Order schedules. $\ldots \ldots \ldots \ldots \ldots \ldots \ldots$

2. INEL ER schedule for transuranic (TRU) pits and trenches with BWID "windows of opportunity." .............................. 5

3. INEL ER and BWID integrated schedule $\ldots \ldots \ldots \ldots \ldots \ldots \ldots \ldots \ldots \ldots \ldots \ldots$

4. Overview schedule for current fiscal year of all TTPs funded by the BWID Program $\ldots \ldots 10$

5. FY-92 analysis, evaluation, and technical program support schedule. $\ldots \ldots \ldots \ldots \ldots 11$

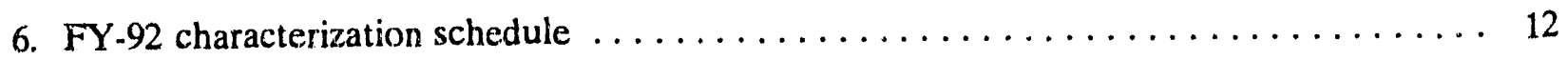

7. FY -92 retrieval and contamination control schedule $\ldots \ldots \ldots \ldots \ldots \ldots \ldots \ldots \ldots$ 
8. FY-92 pretreatment and treatment schedule $\ldots \ldots \ldots \ldots \ldots \ldots \ldots \ldots \ldots \ldots$

9. Out-year TTPs sponsored by BWID overview schedule $\ldots \ldots \ldots \ldots \ldots \ldots \ldots \ldots \ldots$

10. Out-year analysis, evaluation, and technical program support schedule $\ldots \ldots \ldots \ldots$

11. Out-year characterization schedule $\ldots \ldots \ldots \ldots \ldots \ldots \ldots \ldots \ldots \ldots \ldots \ldots$

12. Out-year retrieval and contamination control schedule $\ldots \ldots \ldots \ldots \ldots \ldots \ldots \ldots$

13. Out-year pretreatment and treatment schedule $\ldots \ldots \ldots \ldots \ldots \ldots \ldots \ldots \ldots \ldots \ldots \ldots$

\section{TABLES}

1. Technical Task Plans by Technology Area for FY-92 $\ldots \ldots \ldots \ldots \ldots \ldots \ldots \ldots \ldots$

2. Technical Task Plans (Hold Fund) by technology area for FY $92 \ldots \ldots \ldots \ldots \ldots$

3. Technical Task Plans by technology area for FY-93 through FY $-96 \ldots \ldots \ldots \ldots \ldots$

4. Estimated costs for the currently sponsored Buried Waste

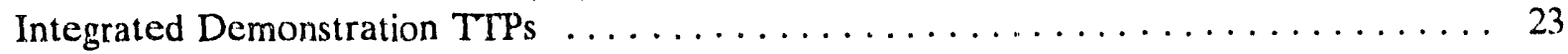




\section{ACRONYMS}

BBEM

BWID

DOE

ER

ERP

FFA/CO

INEL

ITS

LST

NDA

NDE

NEPA

OTD

PCB

RWMC

sow

TER

TMG

TRU

TSR

TTP
Broadband Electromagnetic

Buric d Waste Integrated Demonstration

Department of Energy

Environmental Restoration

Environmental Restoration Program

Federal Facilities Agreement/Consent Order

Idaho National Engineering Laboratory

Integrated Test Schedule

Luminescence Spot Test

Nondestructive Assay

Nondestructive Evaluation

National Environmental Protection Act

Office of Technology Development

polychlorinated biphenyls

Radioactive Waste Management Complex

Statement of Work

Technical Evaluation Report

Tensor Magnetic Gradiometer

transuranic

Technology Status Report

Technology Test Plan or Technical Task Plan 


\section{Integrated Test Schedule for Buried Waste Integrated Demonstration}

\section{INTRODUCTION}

The Waste Technology Development Department of EG\&G Idaho, Inc., is responsible for coordinating and implementing the Buried Waste Integrated Demonstration (BWID) Program. The Department of Energy (DOE) Office of Technology Development (OTD) has initiated the BWID Program to identify, develop, and demonstrate advanced remediation technologies that support DOE's environmental restoration objectives. Technologies to support these environmental restoration activities have evolved and continue to progress as a result of research and development and practical application of these technologies. To more efficiently manage the development and demonstration of these technologies and to enhance the efficacy of the technologies to support buried waste and environmental restoration activities, the BWID Program has developed this working document, the Integrated Test Schedule.

\subsection{Purpose}

The purpose of this document is to integrate individual BWID-sponsored technology schedules and to show the linkage between BWID, the Environmental Restoration Program (ERP), and the Federal Facilities Agreement and Consent Order (FFA/CO).

The Integrated Test $\mathbf{s}$ :edule objectives are to:

- Provide an upper management overview schedule for the technology demonstrations.

- Show synchronous demonstration development to support DOE buried wastes environmental restoration efforts

- Assimilate the schedules of the FFA/CO, the Environmental Restoration Program (ERP), and the technologies demonstrated by BWID.

\subsection{Scope}

The key aspects of this schedule focus on:

- Windows of opportunity to focus BWID demonstrations on Environmental Restoration Program needs.

- Current Year Plan to address BWID planned activities for the current fiscal year

- Out-Year Plan to address BWID activities in the years following the current fiscal year. 
For FY.92 the Integrated Test Schedule will be primarily concentrated on the Idaho National Engineering Laboratory (INEL) FFA/CO schedule. In future years, the Integrated Test Schedule will show the relationship between BWID demonstrations and other DOE FFA/COs.

The schedules in the Integrated Test Schedule will contain information from Technical Task Plans (TTPs) approved as of February 1992, the FFA/COs, and the DOE Idaho Field Office (DOEID) ERP. These schedules also show site-specific imposed milestones for support activities needed to perform the demonstrations. Site-specific imposed milestones define the equipment/facility and regulatory requirements and needs required to perform a demonstration at the INEL. These sitespecific imposed milestones are identified by the operational support task, the regulatory/compliance documentation task, and the facility support/equipment task of the BWID Program TTP.

The TIPs sponsored by BWID are grouped by the Integrated Test Schedule in the following categories:

- Analysis, evaluation, and technical program support

- Characterization

- Retrieval

- Pretreatment/treatment

- Storage

- Transportation

- Disposal.

Initially, BWID will focus on characterization, retrieval, pretreatment/treatment, analysis, evaluation, and technical program support. As the program matures, BWID will refocus with emphasis on storage, transportation, and disposal. BWID demonstrated technologies will support ERP environmental restoration of DOE buried wastes and the FFA/CO enforceable deadlines.

The Integrated Test Schedule is a working document that will be revised annually to incorporate the dev'slopments of new technology and the progress of the BWID Program. 


\section{ENVIRONMENTAL RESTORATION PROGRAM NEEDS}

The Environmental Restoration Program, BWID's primary customer, is responsible for implementing the FFA/CO. To support the Environmental Restoration Program, BWID has identified "windows of opportunity." "Windows of opportunity" are periods of time in which technology demonstrations could support key decisions in the FFA/CO scope.

\subsection{Federal Facility Agreement and Consent Order}

The BWID Program objective is to demons rate technoiogies that can be used to support environmental efforts on DOE buried wastes. Figure 1 shows the FFA/CO schedules for the INEL, Hanford Reservation, Oak Ridge Reservation, and Fernald Environmental Materials Center. FY.92 BWID Program funding directly supports the INEL FFA/CO schedule. In the future, the BWID Program will directly support the other DOE FFA/CO and waste remediation technology deve' ppments will be incorporated in their documents. The INEL Environmental Restoration Roadmap Document, DOE/ID-10364, predecisional draft, dated December 1991, details the need for waste remedication technology development, and facilitates the overall assessment and integration for site-wide planning by identifying specific remediation activities to meet FFA/CO enforcable deadlines. Specifically, this Integrated Test Schedule is in support of the remediation efforts for the INEL's WAG-7 Operating Unit 13 as defined by the INEL FFA/CO.

\subsection{Windows of Opportunity}

As Environmental Restoration (ER) programs identify specific and general needs to support the FFA/CO schedule, BWID will solicit proposals to field and demonstrate technologies that will fulfill those needs. Figures 2 and 3 show the "windows of opportunity" for BWID to field and demonstrate technologies to support environmental restoration programs. These figures also show an overview schedule of BWID, INEL-ER, and FFA/CO schedules and the interrelationship between these schedules and "windows of opportunity" for BWID development of technologies. 


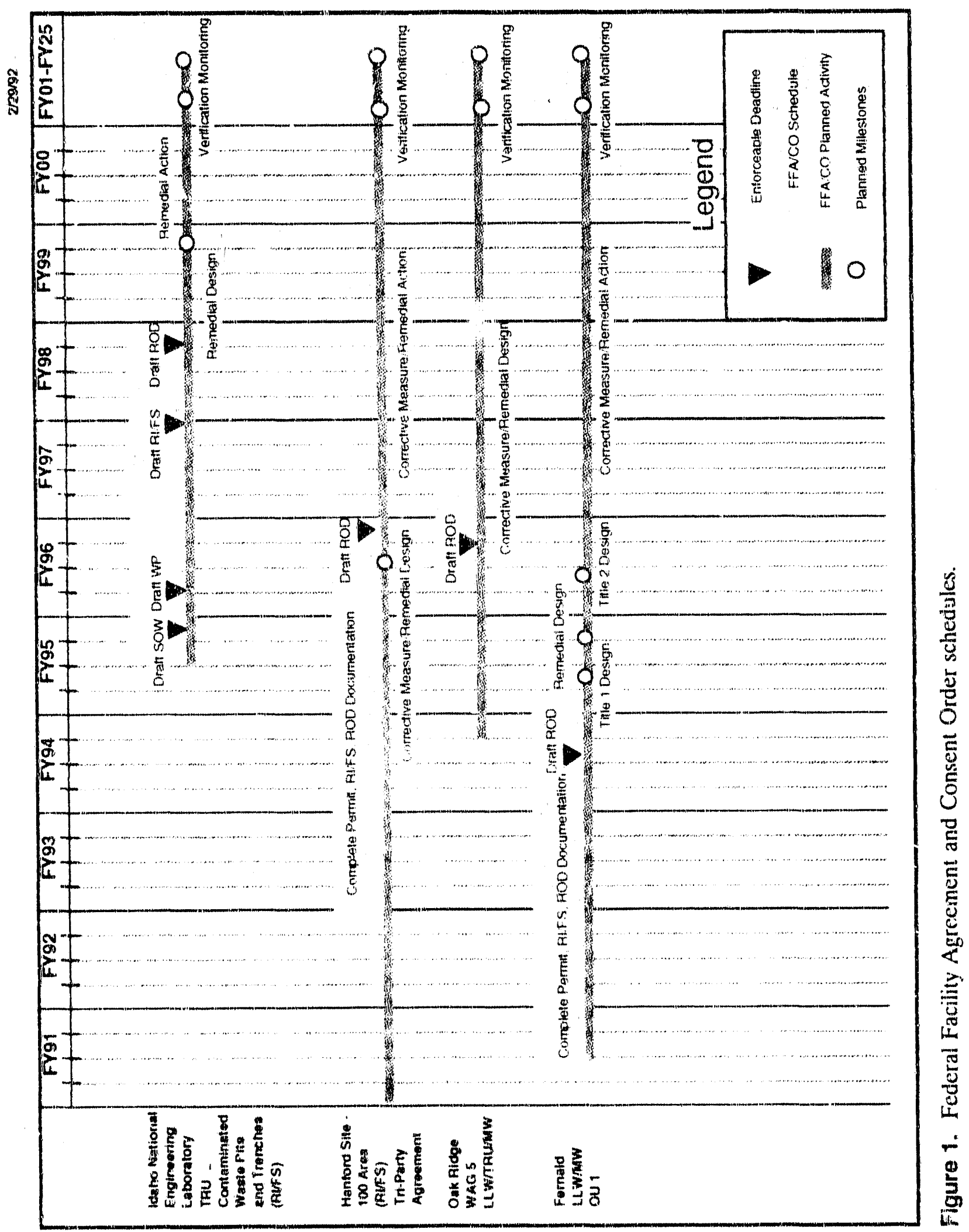




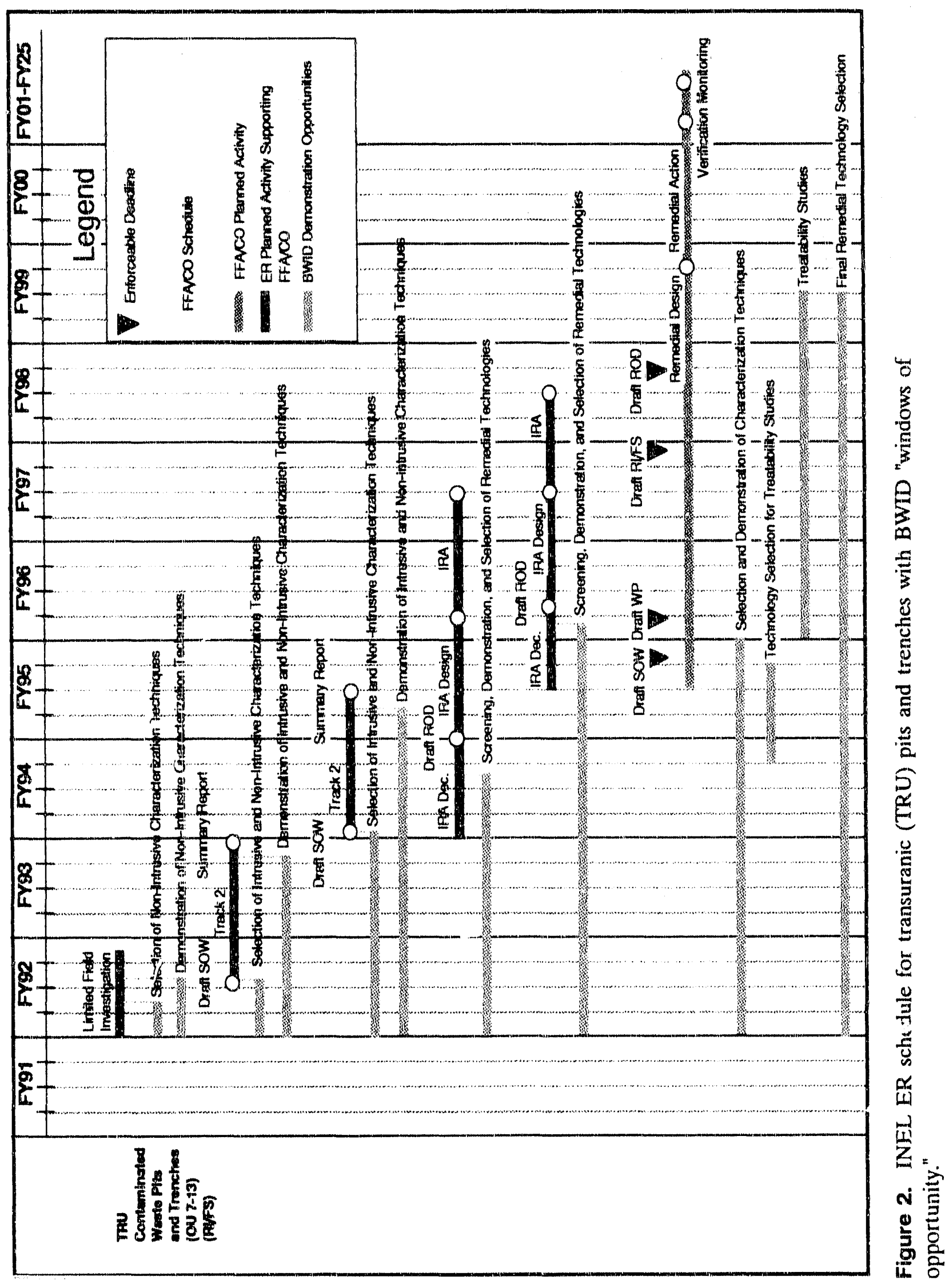




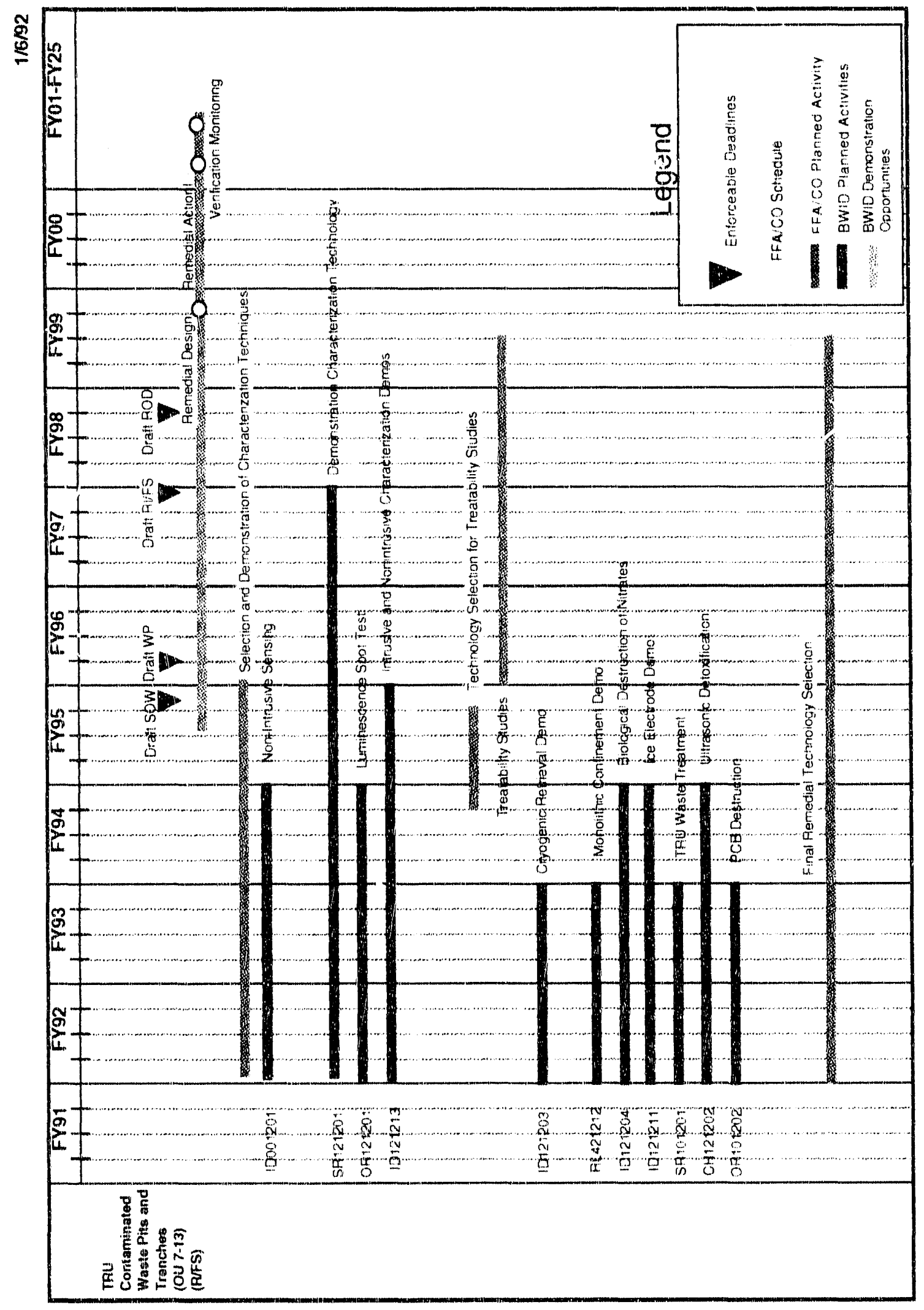

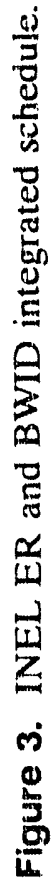




\section{FY-92 SCHEDULE}

This section summarizes FY-92 information from BWID T7 Ps approved as of February 1992. Table 1 shows the technology areas associated with BWID and the TTPs associated with the respective technology area. Table 2 lists the hold fund TTPs. Figure 4 shows an overview schedule for the current fiscal year of all TTPs sponsored by BWID. This figure was developed from information contained in Figures 5 through 8. Figures 5 through 8 show the current fiscal year schedules for each TTP by technology area. These schedules are a compilation of selected activities and milestones reported to BWID in the respective TTPs for the current fiscal year. A detailed description of the technology, including milestones and deliverables, can be found in the respective TTP. These TTPs can be obtained from the BWID program office. 
Table 1. Technical Task Plans by Technology Area for FY-92.

\begin{tabular}{|c|c|c|c|}
\hline \multirow{2}{*}{ Technology Area } & \multirow{2}{*}{ Technical Task Plan Title } & \multicolumn{2}{|c|}{ Technical Task Plan Number } \\
\hline & & Old & New ${ }^{a}$ \\
\hline \multirow{5}{*}{$\begin{array}{l}\text { Analysis, Evaluation, Technical } \\
\text { Program Support }\end{array}$} & Buried Waste Integrated Demonstration Program & ID)-040E2D & ID 111201 \\
\hline & $\begin{array}{l}\text { Decision Support: Buried Waste Integrated Demonstration } \\
\text { (INEL) }\end{array}$ & AL.2202D & Al.101201 \\
\hline & BWID System Design Study & ID.0603.D'T & ID121202 \\
\hline & $\begin{array}{l}\text { Institutional Assessment: Public Acceptability and Regulatory } \\
\text { Feasibility of Buried Waste Integrated Demonstration } \\
\text { Technologies }\end{array}$ & $\mathrm{RL}-8531 \cdot \mathrm{PT}$ & HQ021204 \\
\hline & Complex Buried Waste Assessment & $\begin{array}{l}\text { RL..9739 } \\
(\text { WHC) }\end{array}$ & RLA21213 \\
\hline \multirow[t]{6}{*}{ Characterization } & $\begin{array}{l}\text { TRU/Hazardous Waste Characterization Technologies } \\
\text { (Hold Fund) }\end{array}$ & ID-0799DT & ID021204 \\
\hline & NDE/NDA Peer Review & HQ-920016 & HQ021203 \\
\hline & Demonstration Characterization Technology & SR-0620-AA & SR: 121201 \\
\hline & Field Demonstration of Characterization Technologies & ID. 920007 & ID121213 \\
\hline & $\begin{array}{l}\text { Non-Intrusive Sensing of Environmentally Important Objects } \\
\text { and Species }\end{array}$ & ID.2520-GA & ID001201 \\
\hline & $\begin{array}{l}\text { Rapid and Cost-Effective Luminescence Spot Test (LST) } \\
\text { for Screening PCBs }\end{array}$ & $\mathrm{OK}-0367-\mathrm{AY}$ & OR121201 \\
\hline \multirow[t]{3}{*}{ Retrieval } & Cryogenic Retrieval & ID-0604-DT & ID121203 \\
\hline & TRU Waste Treatment Methodology & SR-D088-AA & SR101201 \\
\hline & $\begin{array}{l}\text { Retrieval Suppon Contamination Control Technologies } \\
\text { (Hold Fund) }\end{array}$ & ID-0797DT & ID121206 \\
\hline \multirow{8}{*}{$\begin{array}{l}\text { Pretreatment/ } \\
\text { Treatment }\end{array}$} & Pad A Treatability Study & ID-0610-DT & ID 121205 \\
\hline & Biological Destruction of Nitrates & ID-0607-DT & ID121204 \\
\hline & Ultrasonic Process for Detoxifying Groundwater and Soil & $\mathrm{CH}-1153-00$ & $\mathrm{CH} H 201202$ \\
\hline & Thermal Processing Technologies (Hold Fund) & ID. $.0798 \mathrm{DT}$ & ID 121207 \\
\hline & $\begin{array}{l}\text { Monolithic Confinement of RWMC Contaminated } \\
\text { Geological Media }\end{array}$ & RL-9734-PT & RL421212 \\
\hline & Destruction of PCBs in Mixed Wastes & OR-0373-AL & OR 101202 \\
\hline & Treatment Technology for TRU Waste & RL-9021 & RL301203 \\
\hline & Ice Electrodes & ID-9200-08 & ID121211 \\
\hline
\end{tabular}


Table 2. Technical Task Plans (Hold Fund) by technology area for FY-92.

\begin{tabular}{|c|c|c|c|}
\hline \multirow{2}{*}{ Technology Area } & \multirow{2}{*}{ Technical Task Plan Title } & \multicolumn{2}{|c|}{ Technical Task Plan Number } \\
\hline & & Old & $\mathrm{New}^{\mathrm{a}}$ \\
\hline \multirow[t]{5}{*}{ Characterization } & Improved TRU Waste & AL-PROP 13 & $\sin 121209$ \\
\hline & Radiological and Hazardous Materials & ID-0608DT & ID121212 \\
\hline & LINAC-based NDA/NDE of RH TRU & OR-10372AE & OR021201 \\
\hline & NDE Evaluation Characterization & SF-920011 & SF021201 \\
\hline & NDE TRU & RL-920017 & RL021204 \\
\hline \multirow[t]{4}{*}{ Retrieval } & Contamination Control & ID-0605DT & ID 121210 \\
\hline & Gas Cuntamination & AL-PROP 14 & AL021201 \\
\hline & Realtime Monitoring & AL-PROP15 & AL.121210 \\
\hline & Electrostatic Aerosol Sampler & AL-920039 & $\mathrm{AL} 121202$ \\
\hline \multirow[t]{8}{*}{ Treatment } & Thermal Processing & ID-0602DT & ID021202 \\
\hline & Butte Plasma Arc Furnace & ID-3001B1 & ID001202 \\
\hline & Vitrification of Mixed TRU & RL-920014 & RL021202 \\
\hline & DC Arc Plasma and Ceramic Melter & RL-Y20015 & RLO21203 \\
\hline & Molten Salt Processing & SF-150601 & SF001201 \\
\hline & RF Compacted Waste & ID-3005B1 & ID001203 \\
\hline & Supercriticial Oxidation & AL-920040 & Al121208 \\
\hline & Joule Gas Melter & $R F-4200$ & RF101204 \\
\hline
\end{tabular}

a. Numbers as defined by the Office of Technology Developmenı FY-92 Program Guidance. 


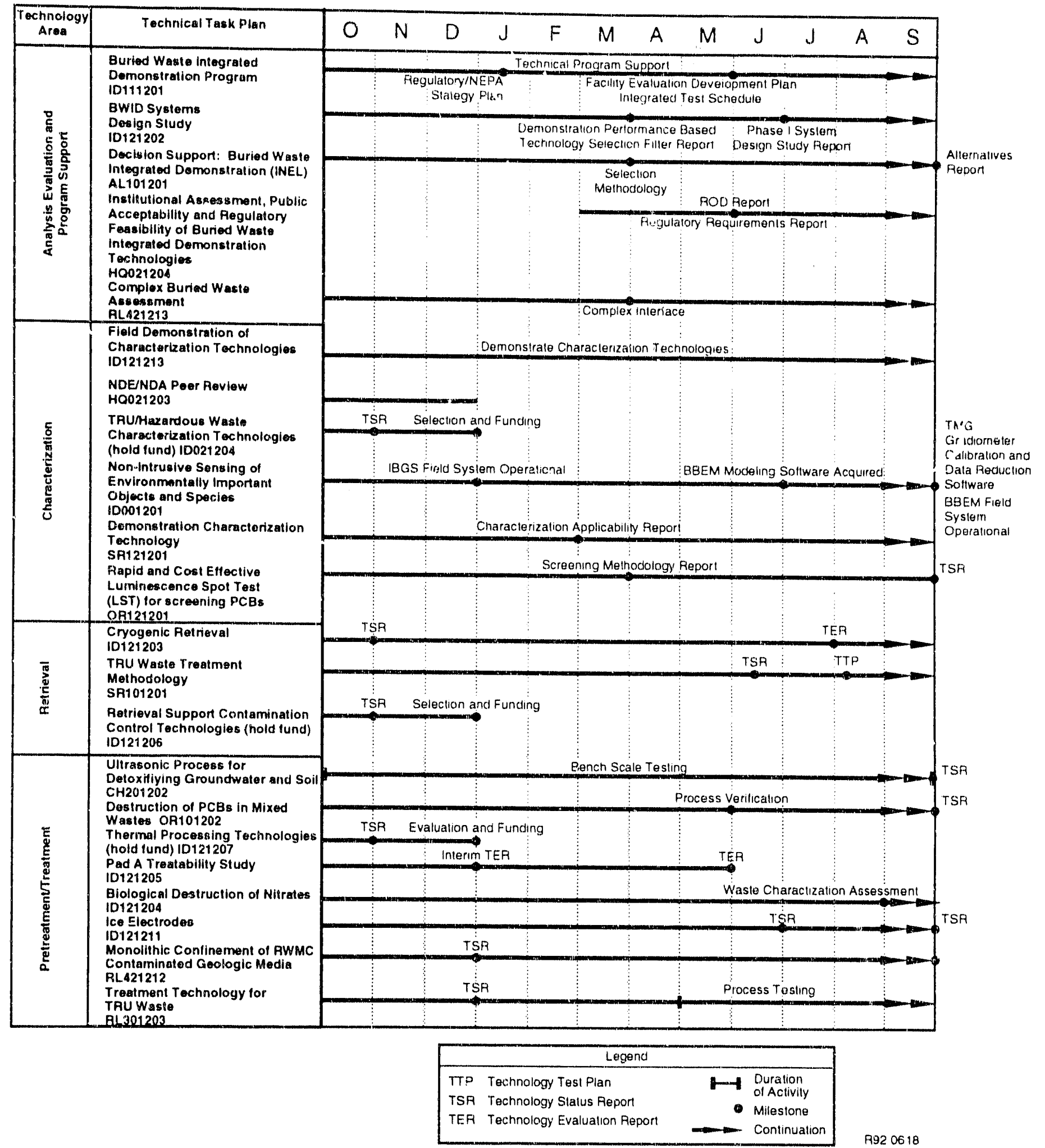

Figure 4. Overview schedule for current fiscal year of all TTPs funded by the BWID Program. 


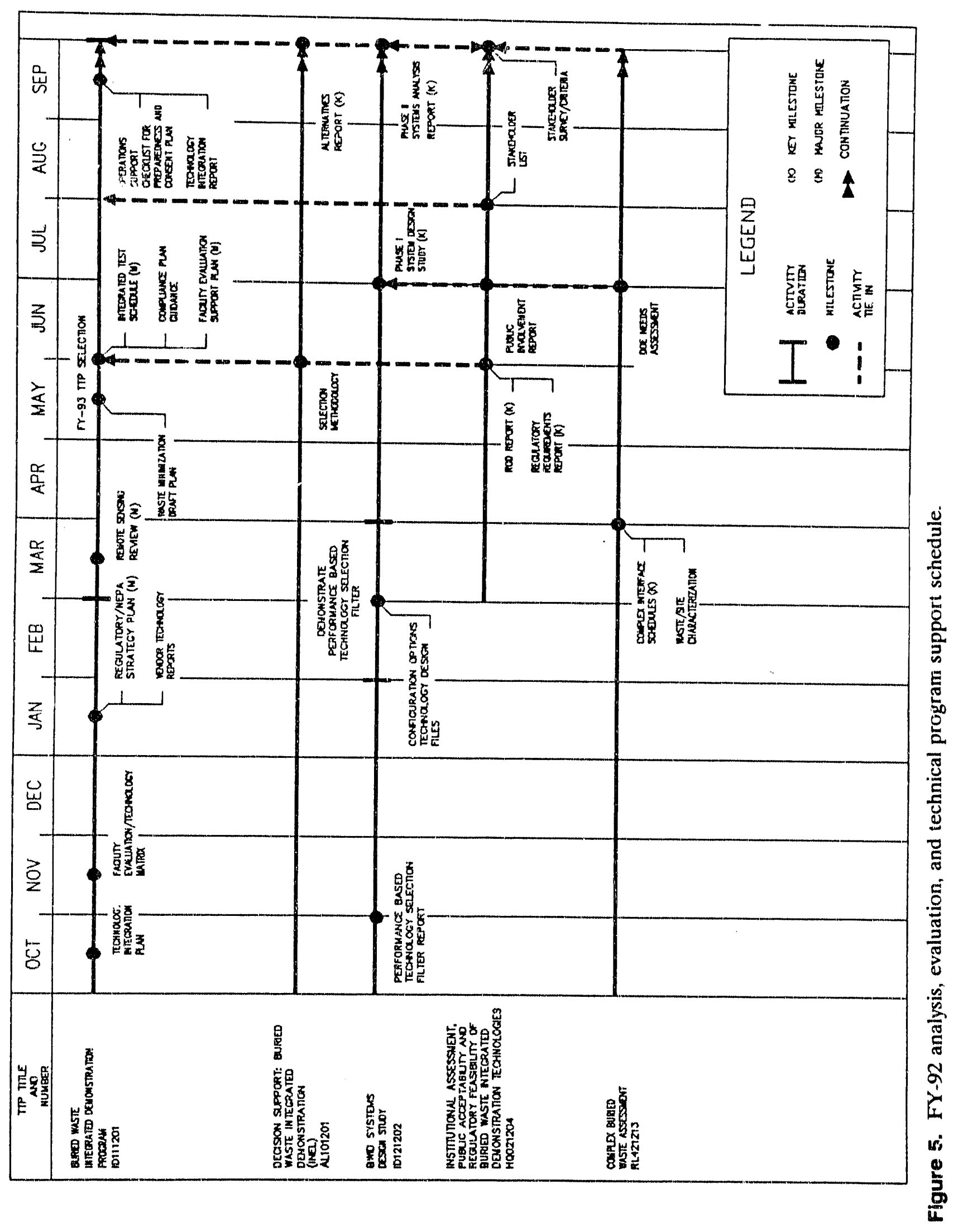




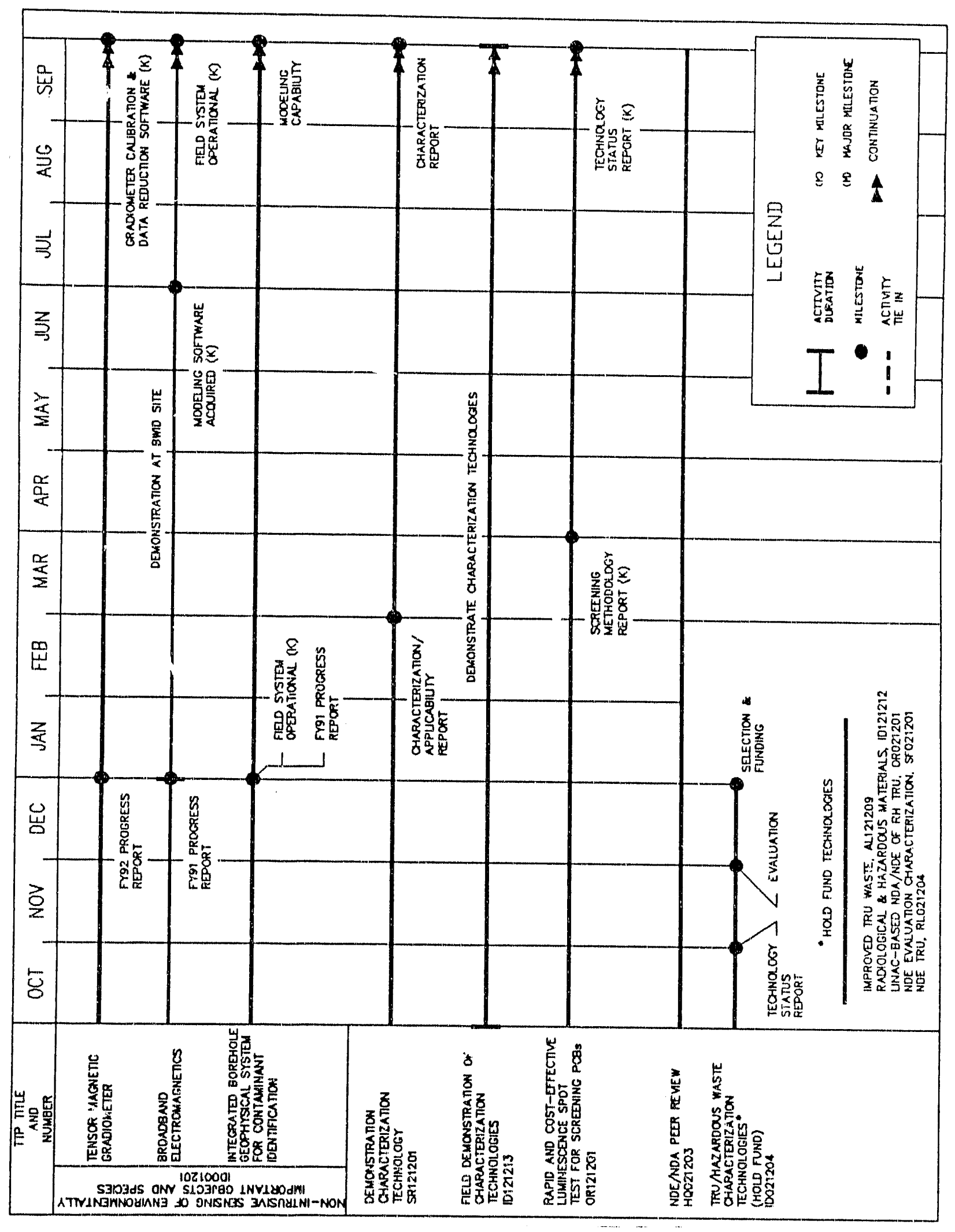

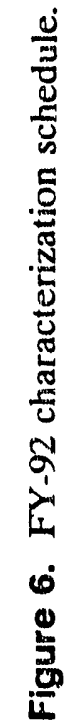




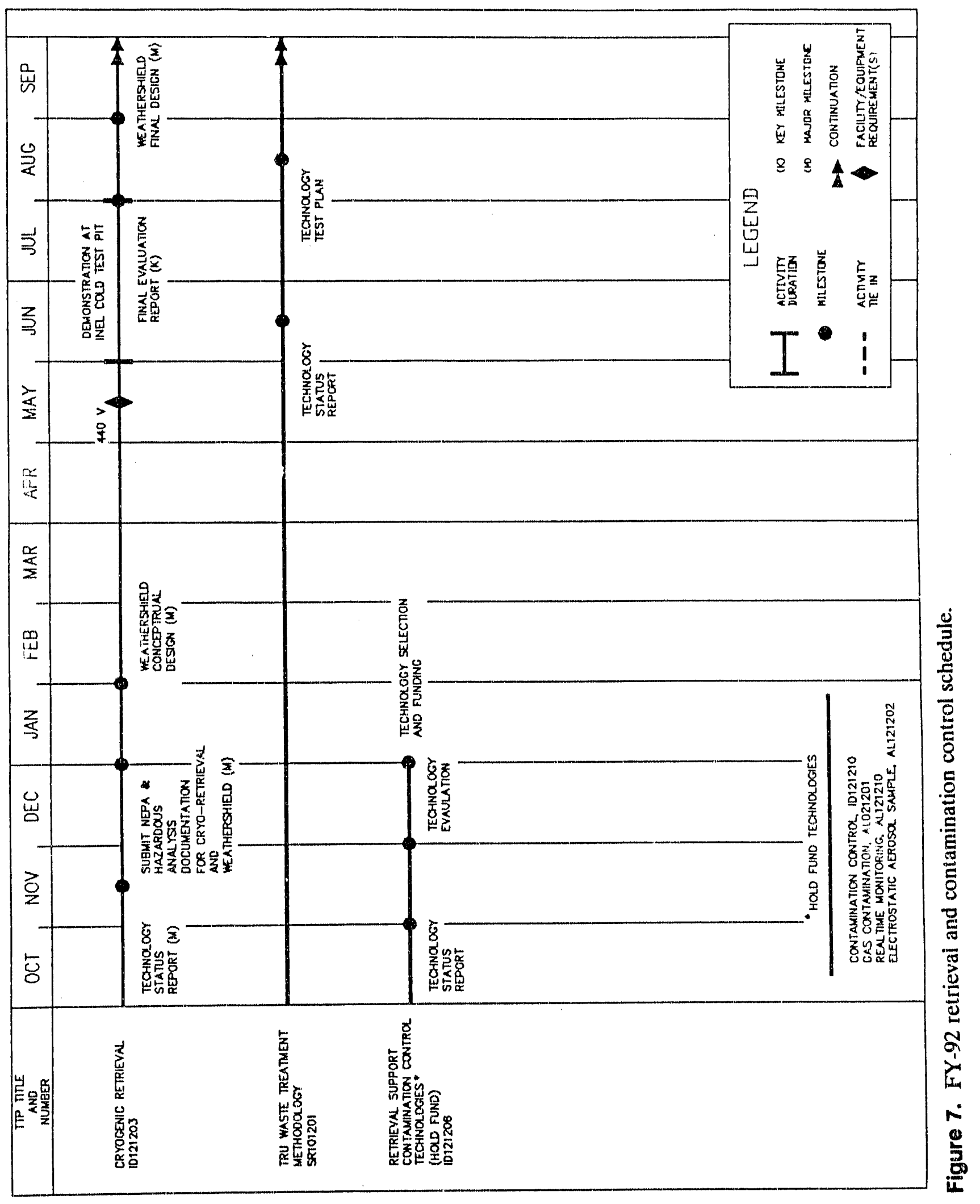




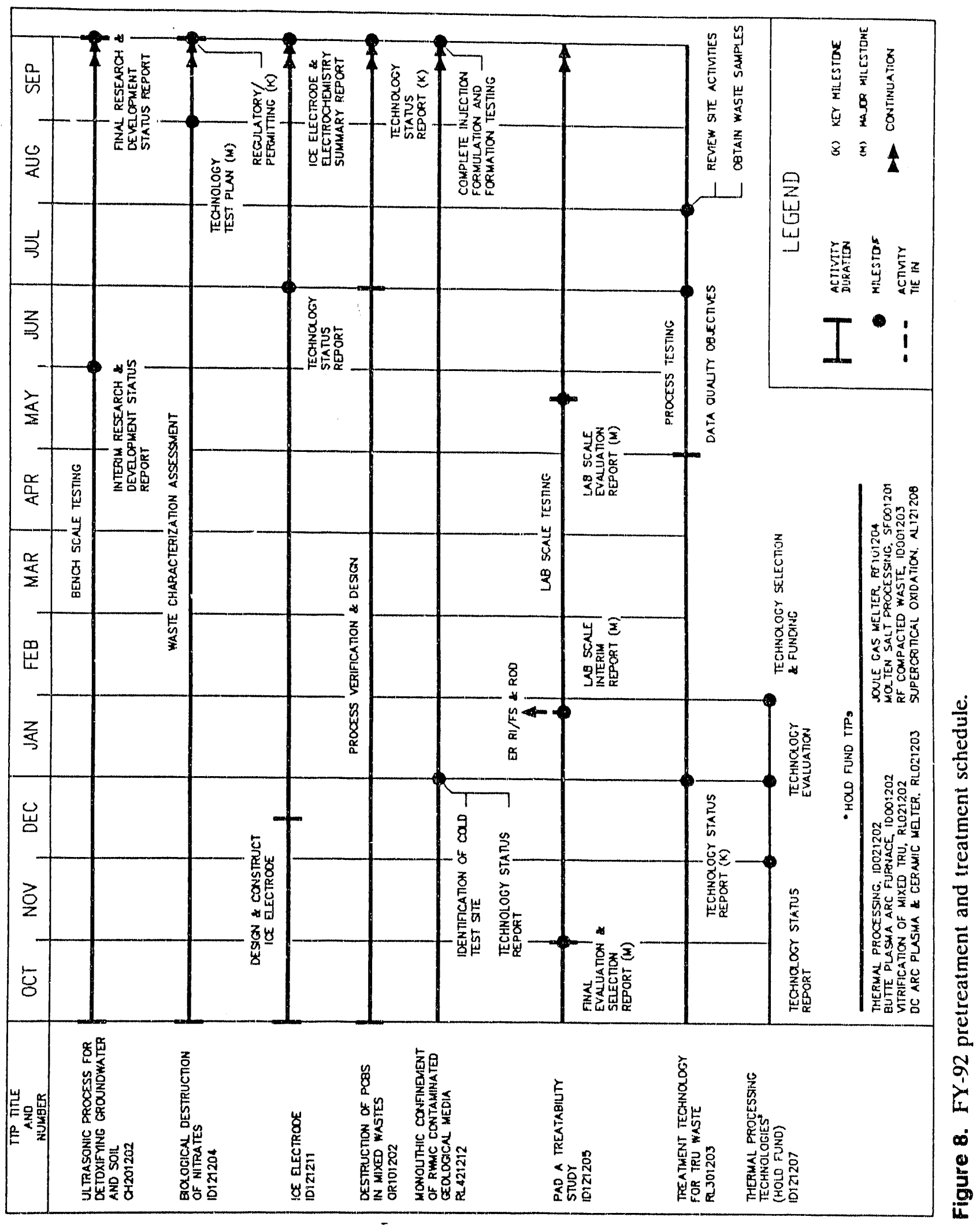




\section{OUT-YEARS SCHEDULES}

This section summarizes out-year information from BWID TTPs approved as of February 1992. Table 3 shows the technology areas associated with BWID and the TTPs associated with the respective technology arca. Figure 9 shows an overview schedule for the out-years of all TTPs sponsored by BWID. This figure was developed from information contained in Figures 10 through 13. Figures 10 through 13 show the out-year schedules for each TTP by technology area. These schedules are a compilation of selected activities and milestones reported to BWID in the respective TTPs for the out-years. A detailed description of the technology, including milestones and deliverables, can be found in the respective TTP. These TTPs are available from the BWID program office. 
Table 3. Technical Task Plans by technology area for FY-93 through FY-96.

\begin{tabular}{|c|c|c|c|}
\hline \multirow{2}{*}{ Technology Area } & \multirow{2}{*}{ Technical Task Plan Titte } & \multicolumn{2}{|c|}{ Technical Task Plan Number } \\
\hline & & Old & $\mathrm{New}^{\mathrm{a}}$ \\
\hline \multirow[t]{4}{*}{$\begin{array}{l}\text { Anaivsis, Evaluation, Program } \\
\text { Support }\end{array}$} & Buried Waste Integrated Demonstration Program & ID-040E-2D & ID111201 \\
\hline & $\begin{array}{l}\text { Decision Support: Buried Waste Integrated Demonstration } \\
\text { (INEL) }\end{array}$ & $A L-2202 D$ & AL,101201 \\
\hline & BWID System Design Study & ID-0603-DT & ID121202 \\
\hline & $\begin{array}{l}\text { Institutional Assessment: Public Acceptability and Regulatory } \\
\text { Feasibility of Buried Waste Integrated Demonstration } \\
\text { Technologies }\end{array}$ & RL-8513 & HQ021204 \\
\hline \multirow[t]{4}{*}{ Characterization } & Demonstration Characterization Technology & SR-0620-AA & SR121201 \\
\hline & Field Demonstration of Characterization Technologies & ID -920007 & ID $12: 213$ \\
\hline & $\begin{array}{l}\text { Non-Intrusive Sensing of Environmentally Irnportant Objects } \\
\text { and Species }\end{array}$ & ID-2520-GA & ID001201 \\
\hline & $\begin{array}{l}\text { Rapid and Cost-Effective Luminescence Spot Test (LST) } \\
\text { for Screening PCBs }\end{array}$ & OR-0367-AY & OR 121201 \\
\hline \multirow[t]{2}{*}{ Retrieval } & Cryogenic Retrieval & ID-0604-DT & ID121203 \\
\hline & TRU Waste Treatment Methodolisgy & SR-0088-AA & SR101201 \\
\hline \multirow[t]{7}{*}{ Pretreatment/treatment } & Pad $\fallingdotseq$ Treatability Study & ID-0610-DT & ID121205 \\
\hline & Biological Destruction of Nitrates & ID-0607-DT & ID121204 \\
\hline & Ultrasonic Process for Detoxifying Groundwater and Soil & $\mathrm{CH}-115300$ & CH201202 \\
\hline & $\begin{array}{l}\text { Moisolithic Confinement of RWMC Contaminated } \\
\text { Geological Media }\end{array}$ & RL-9734 & RLA21212 \\
\hline & Destruction of PCBs in Mixed Wastes & OR-0373-AL & OR101202 \\
\hline & Treatment Technology for TRU Waste & RL-9021 & RL301203 \\
\hline & Ice Electrodes & ID-920008 & ID121211 \\
\hline
\end{tabular}




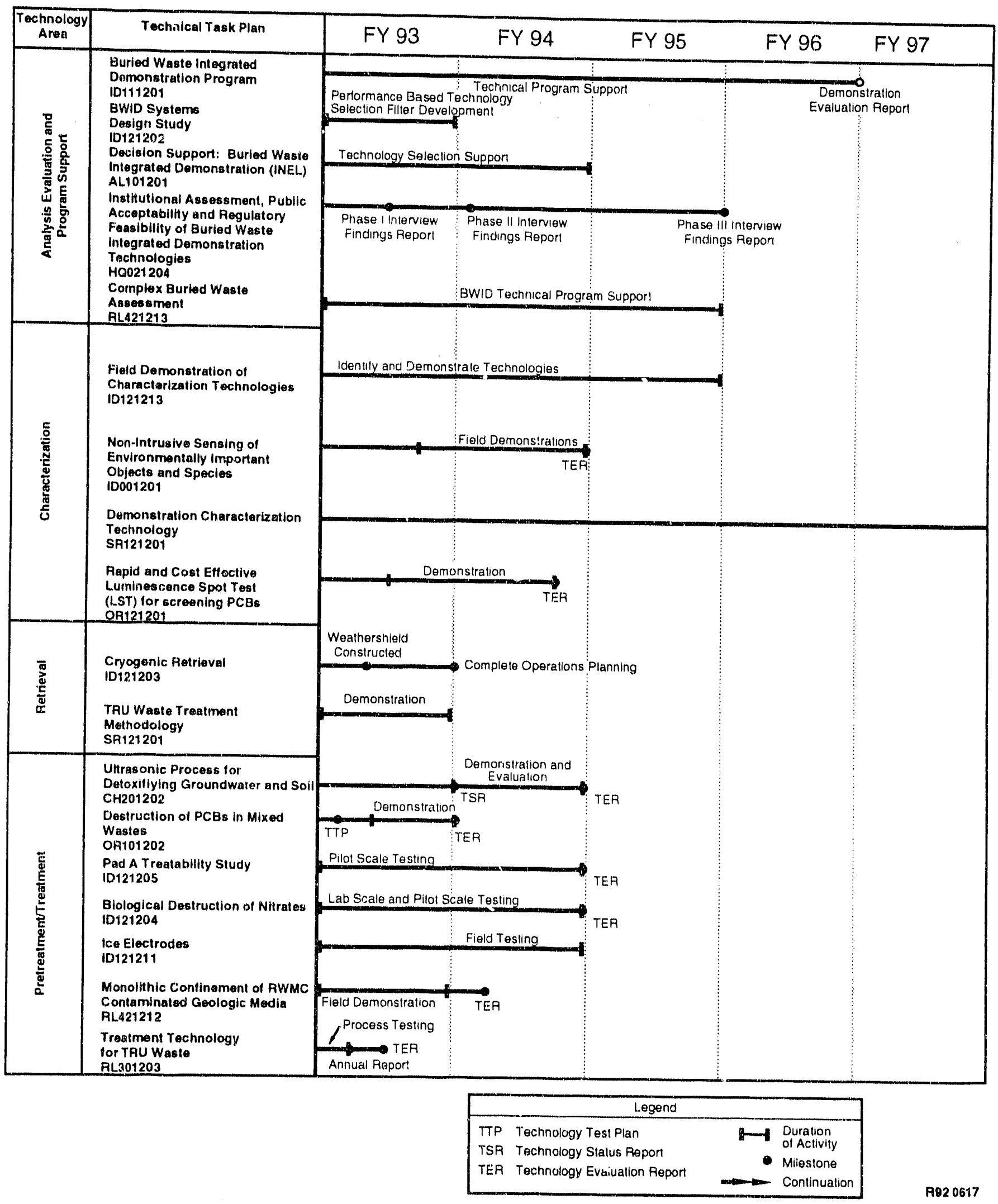

Figure 9. Out-year TTPs sponsored by BWID overview schedule. 


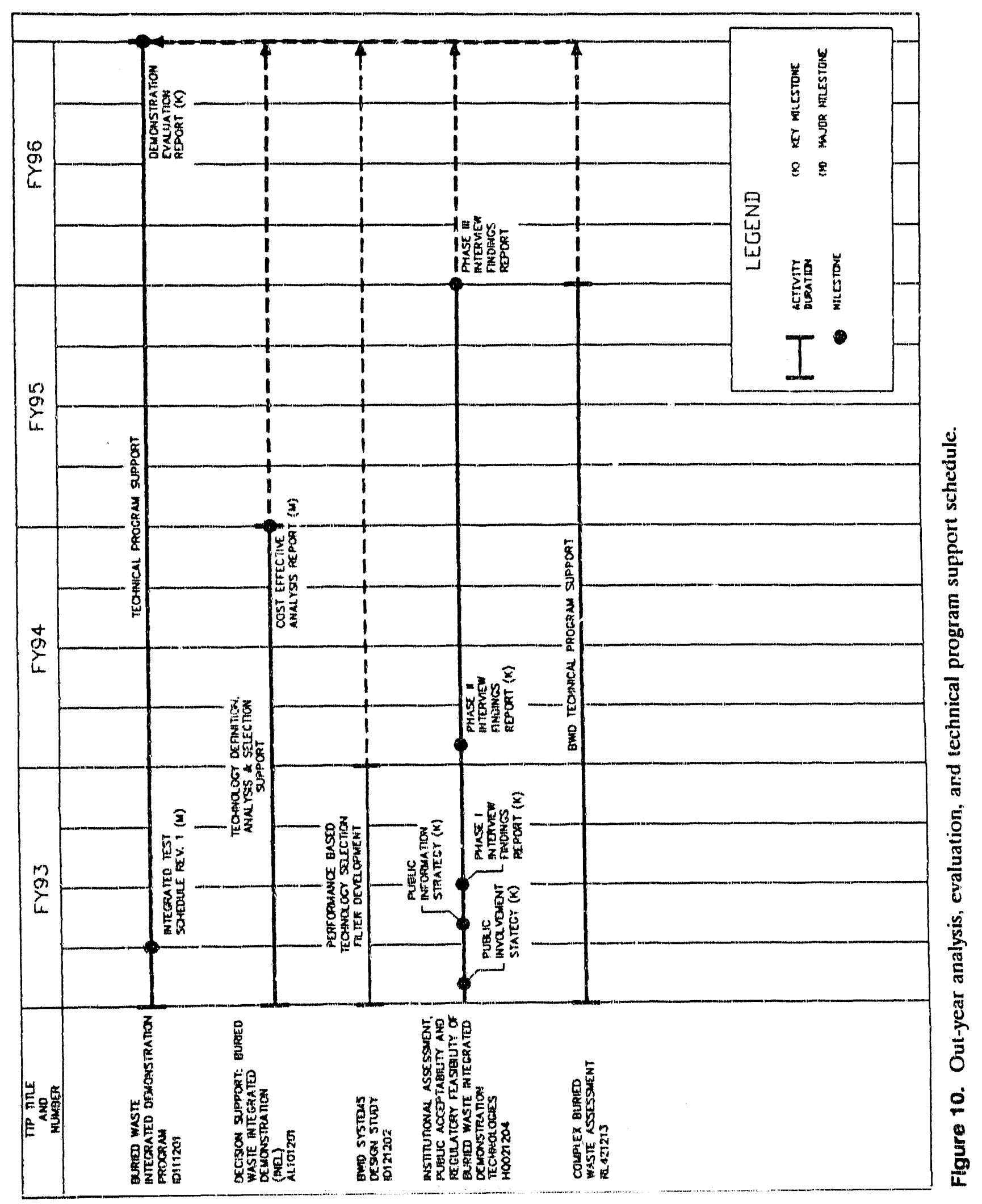




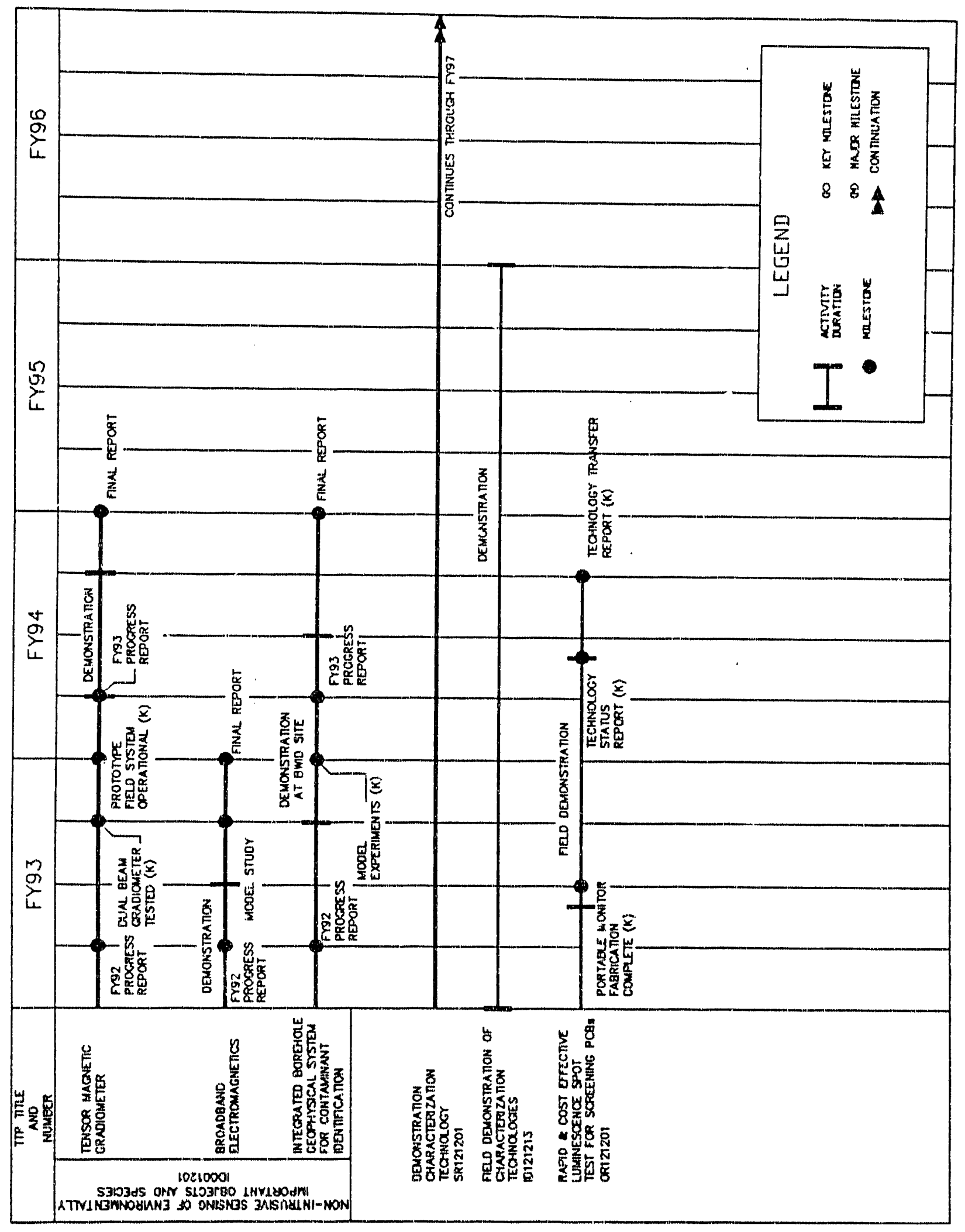

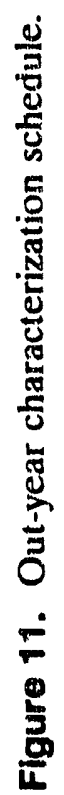




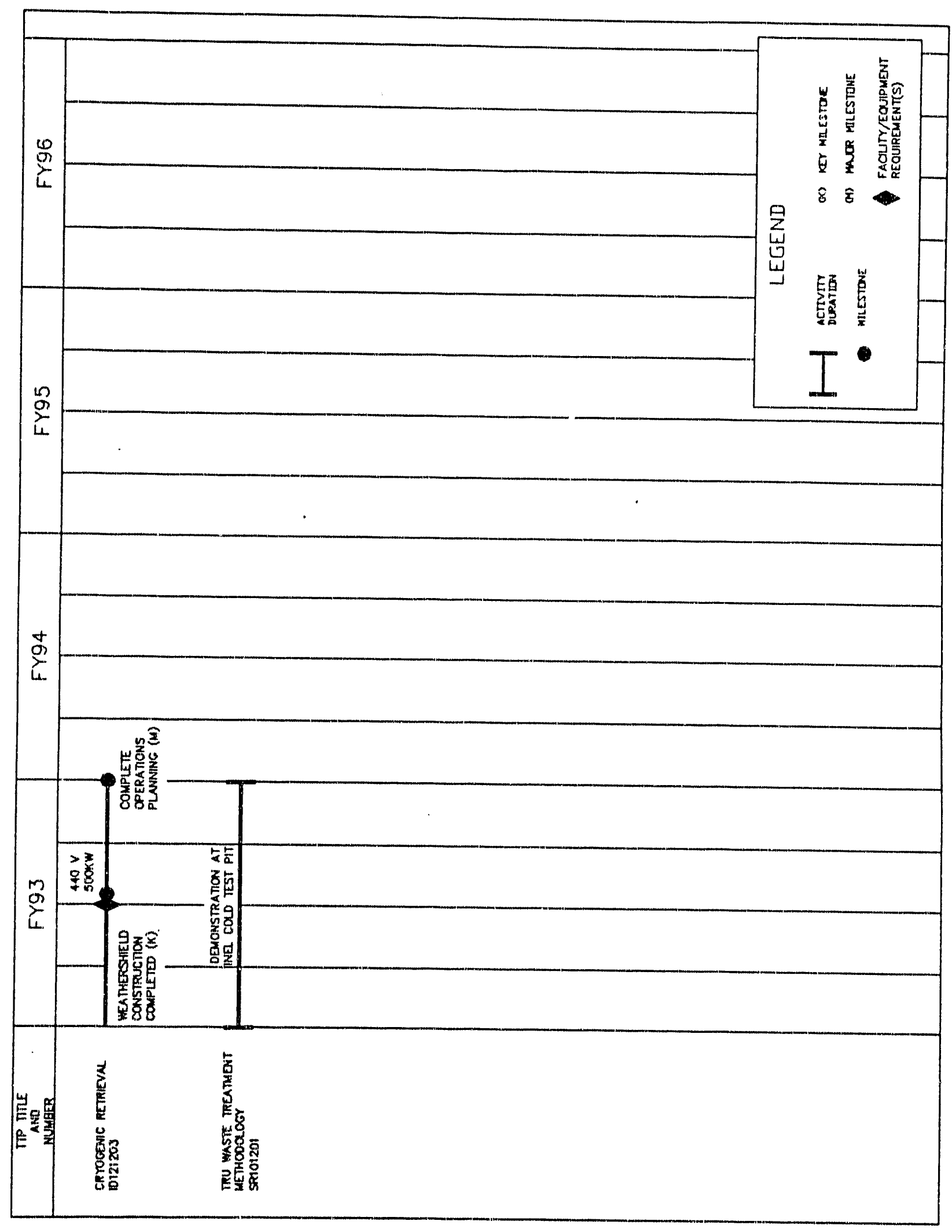

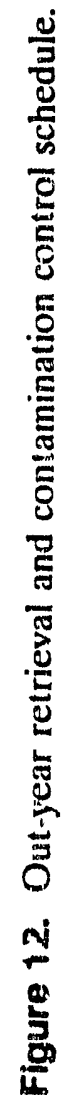




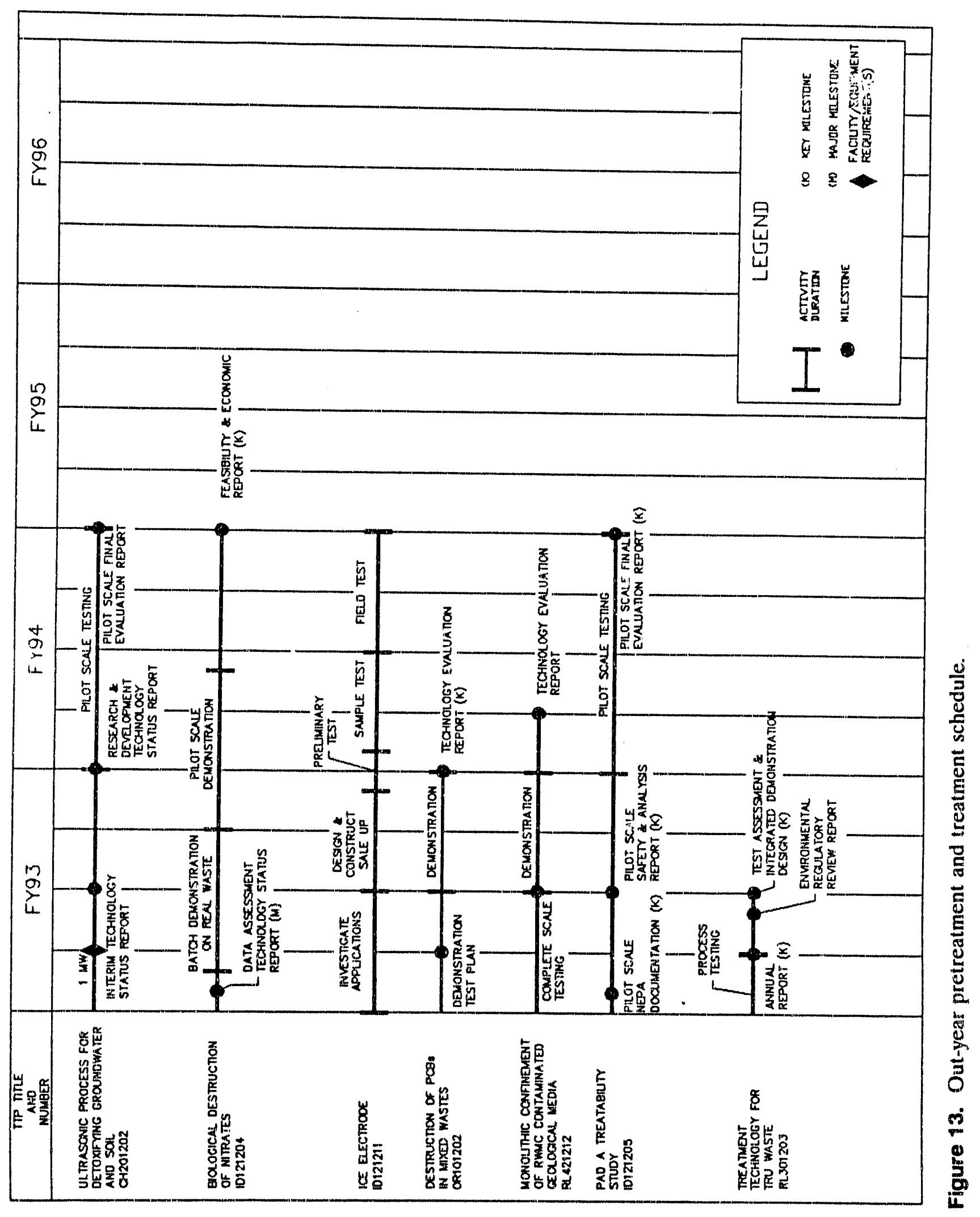




\section{5. $\cos T$}

Estimated costs for the Buried Waste Integrated Demonstration are shown in Table 4. The costs identified were taken from the Technical Task Plans (TTPs) developed by the principal investigators. For FY-92 per January 1992 OTD guidance, estimated costs are $\$ 19.4 \mathrm{M}$. Total estimated costs for the TTPs currently sponsored by BWID for FY -92 through FY-97 are \$74.756M. Table 4 also shows the estimated costs associated with each TTP by year, the total estimated cost of the TTP, the estimated costs associated with each technology area (i.e., characterization, retrieval, pretreatment/treatment, storage, transportation, analysis, evaluation, and program support) by year, and the total estimated costs by technology area. 


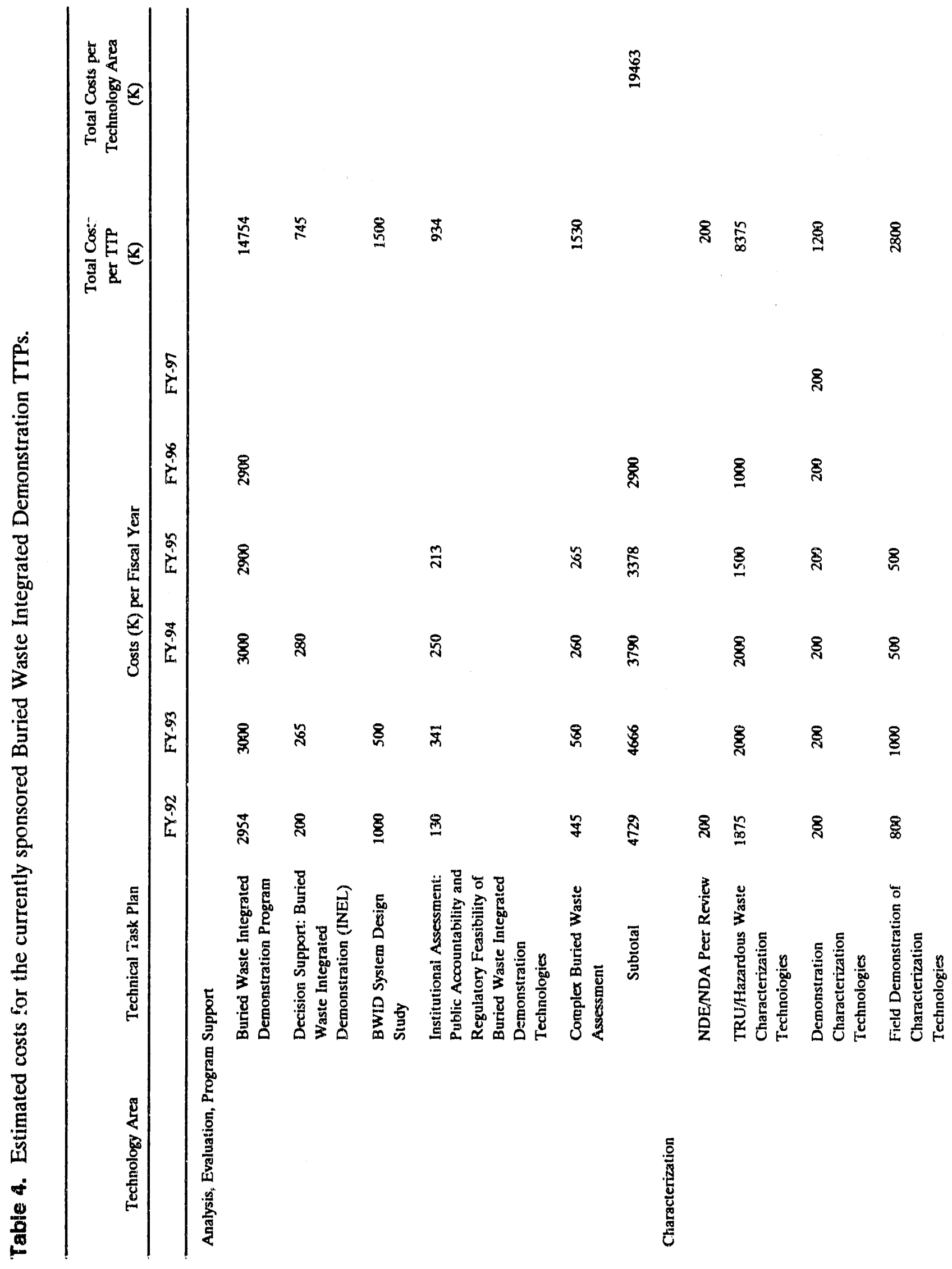




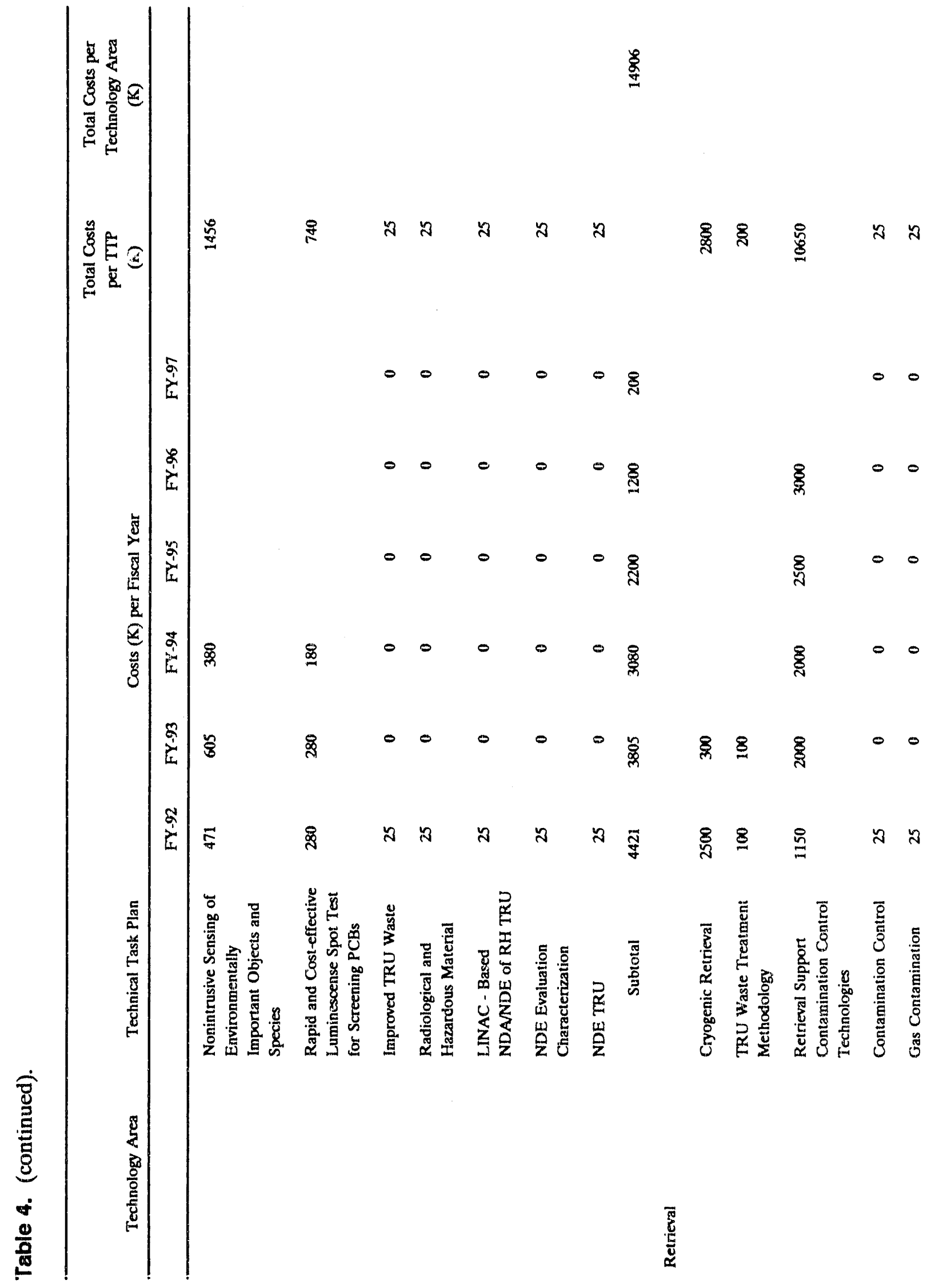




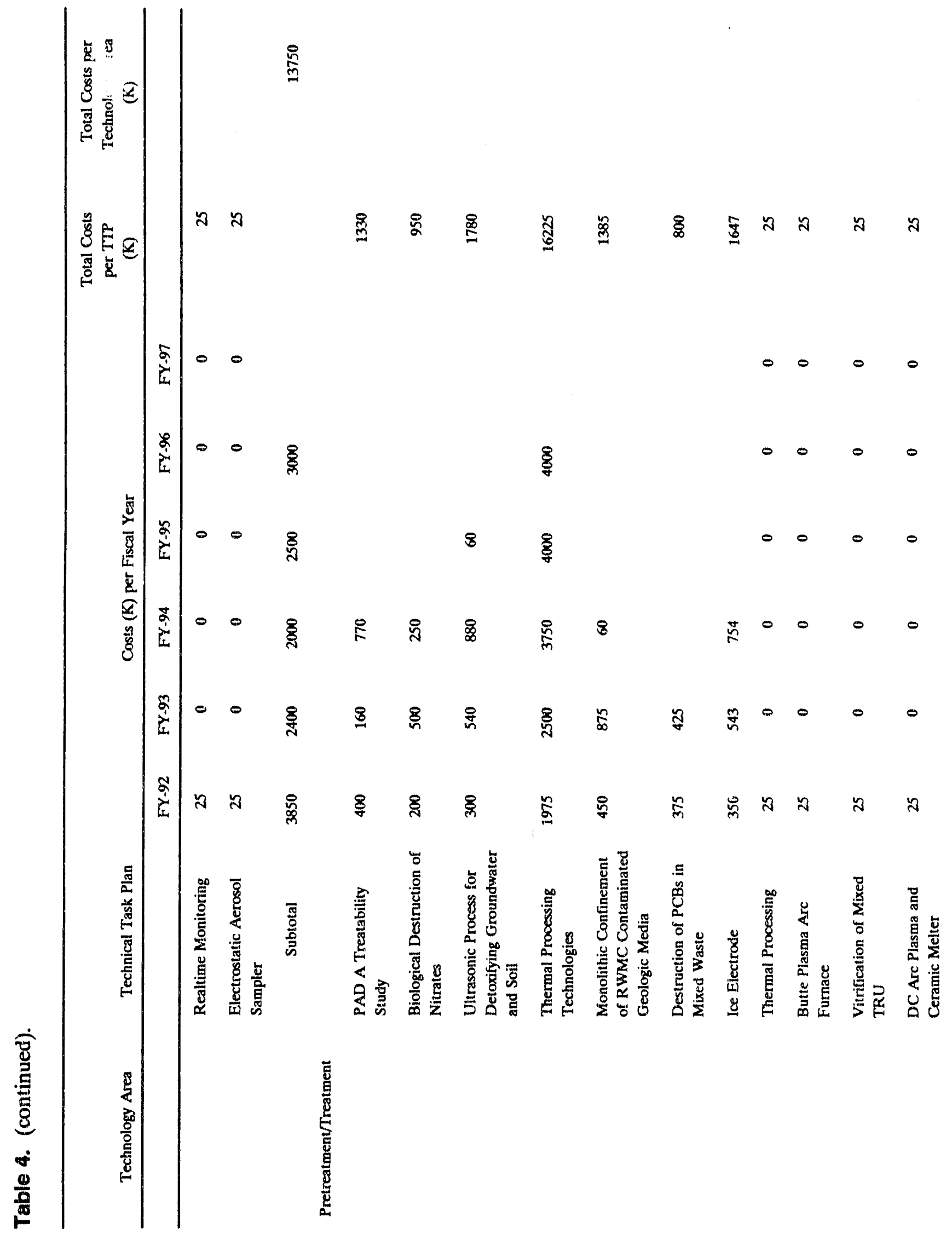




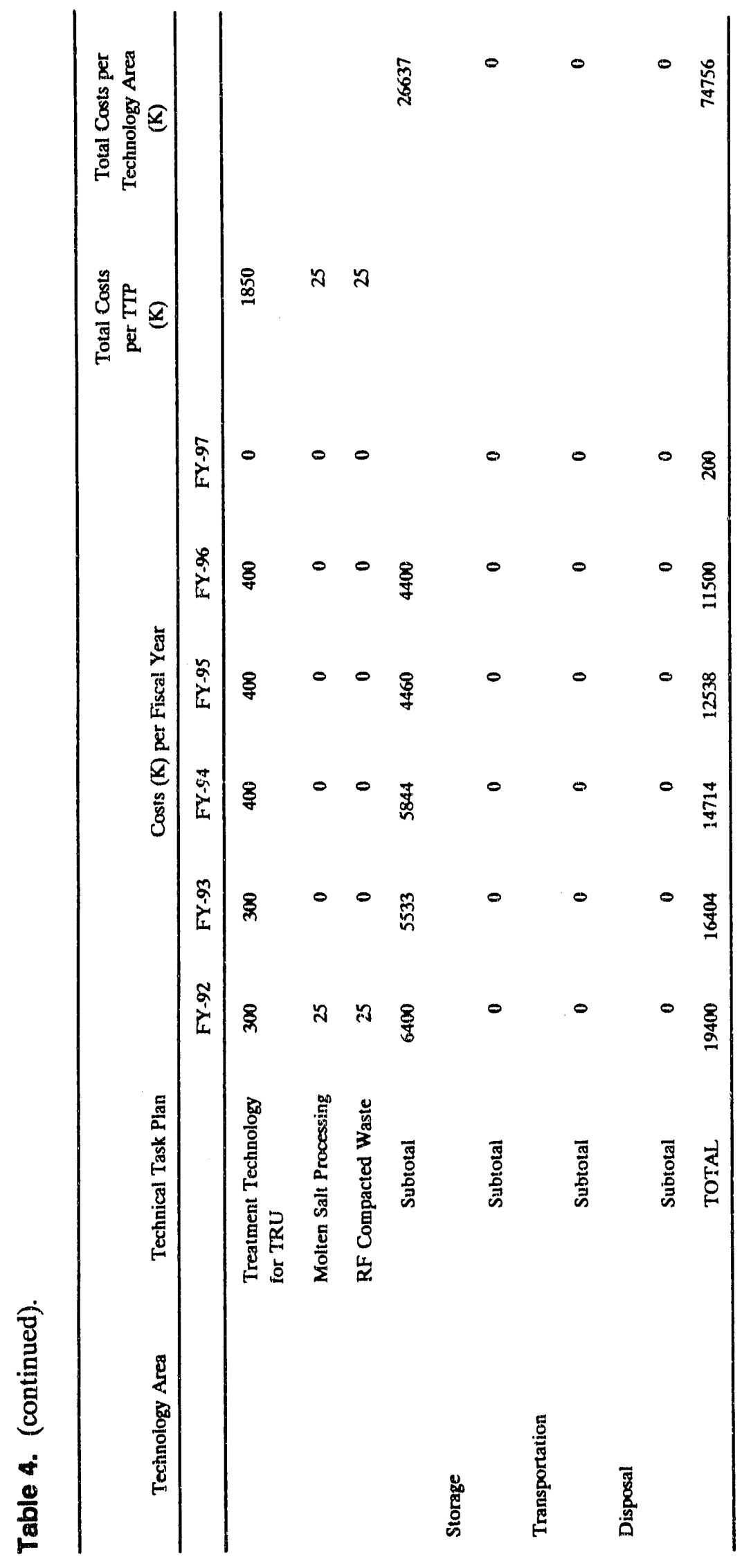




\section{BIBLIOGRAPHY}

EG\&G Idaho, Inc., Technical Task Plans

Federal Facility Agreement, Consent Order, and Action Plan for Implementation thereof, for the Idaho National Engineering Laboratory (Between the State of Idaho, Department of Health and Welfare; the United States Environmental Protection Agency, Region 10; and the United States Department of Energy, Idaho Field Office), December 4, 1991.

K. M. Kostelnik, Buried Waste Integration Demonstration Plan, EGG-WTD-9870, December 1991.

United States Department of Energy, Idaho National Engineering Laboratory Environmental Restoration Roadmap Document, Predecisional Draft, DOE/ID-10364, December 1991.

United States Department of Energy, Office of Technology Development, FY 92 Program Guidance, January 1992. 

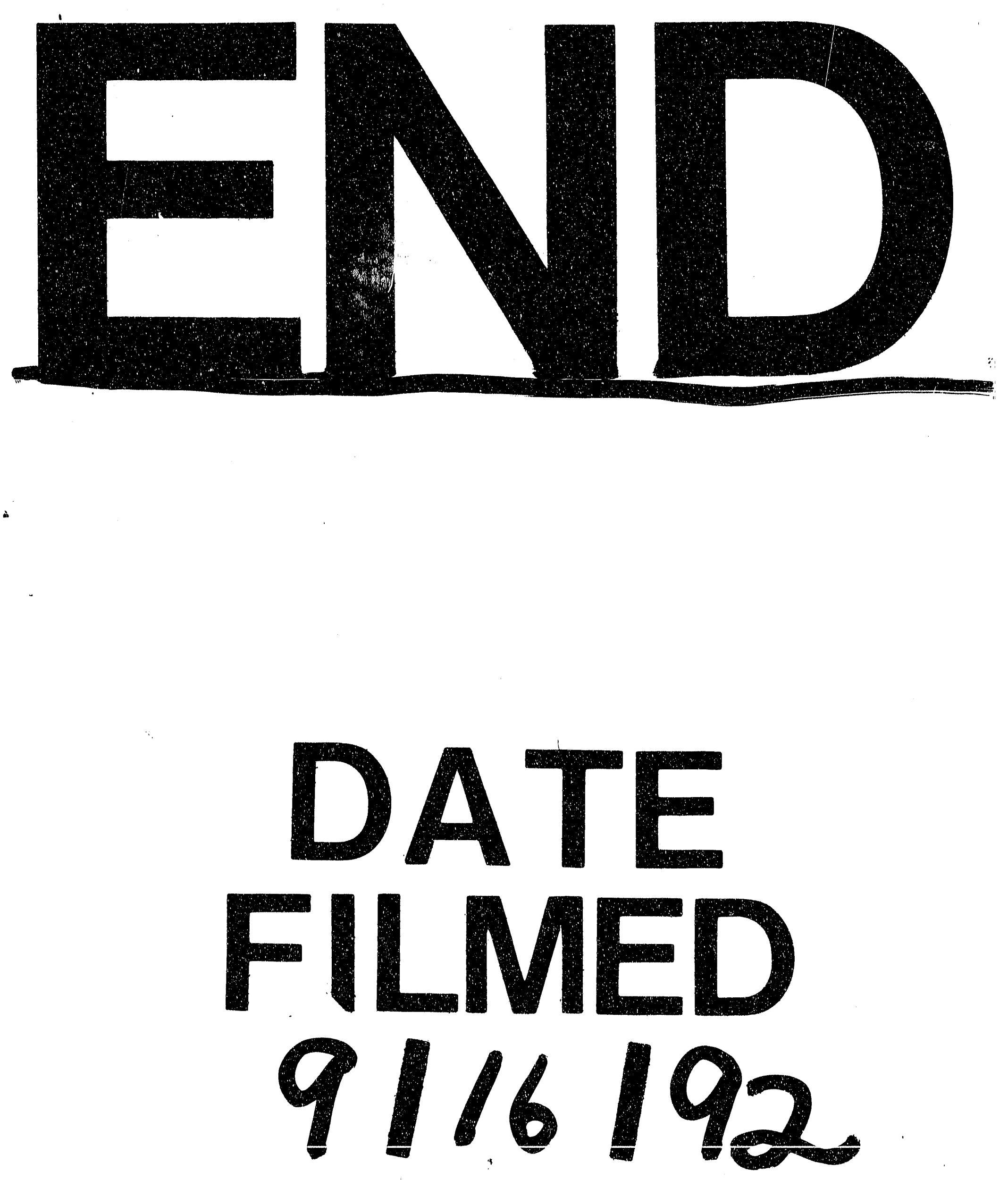
1 